\title{
'Is every YouTuber going to make a coming out video eventually?': YouTube celebrity video bloggers and lesbian and gay identity
}

\author{
Michael Lovelock, University of East Anglia \\ Post-print manuscript accepted for publication in Celebrity Studies. \\ Doi: Forthcoming \\ The research for this article was funded by a Doctoral Studentship grant from the Arts \\ and Humanities Research Council.
}

A significant number of YouTube celebrity video bloggers (vloggers) have used the platform to come out publicly as lesbian or gay. This article interrogates the cultural work of YouTube celebrity coming outs, through the case studies of two of the most prominent gay vloggers: Ingrid Nilsen and Connor Franta. This article explores how the coming out moments of these vloggers, as articulated in their coming out vlogs and the wider media discourses surrounding these, make legible a normative gay youth subject position which is shaped by the specific tropes, conventions and commercial rationale of YouTube fame itself. I define this subject position as 'proto-homonormative.' It positions a "successful" gay adulthood, defined through the neoliberal ideals of authenticity, self-branding and individual enterprise bound to the phenomenon of YouTube celebrity, as contingent upon a particular personal relationship with one's non-normative sexuality. I interrogate how the emotional contours of Nilsen and Franta's coming out narratives, their represented abilities to channel their non-normative sexualities into lucrative celebrity brands, and their construction as gay and lesbian 'role models' by the mainstream media, delineates a journey into "acceptance" and "pride" in one's gay sexuality as the expected narrative of contemporary gay life. This narrative, I argue, cements the default normativity of heterosexuality in mainstream culture, and produces a narrow framework of "acceptable" gay youth subjectivity which is aligned with the ideals of neoliberalism embodied in the figure of the YouTube celebrity vlogger. 
Keywords: YouTube, vlogs, gay identity, coming out, homonormativity

\section{$\underline{\text { Introduction }}$}

In recent years, the phenomenon of YouTube celebrity has come the forefront of popular culture. Within the emerging pantheon of YouTube stars, openly gay and lesbian video bloggers (or 'vloggers') have become highly visible in a way rarely found in traditional media. As Gay Times magazine has noted, lists of the most popular YouTube personalities are 'almost completely complied of LGBT YouTubers like Tyler Oakley, Connor Franta and Ingrid Nilsen' (Dillon, 2015); a list to which we could add many others, such as Joey Graceffa, Troye Sivan, Hannah Hart and Aaron and Austin Rhodes. Significantly, almost all of these figures have come out publicly as lesbian or gay after becoming famous as YouTube vloggers. YouTube celebrity has thus become a central space not only for the representation of gay identities, but for the circulation of particular scripts of coming out - so much so that YouTube celebrity coming outs have almost descended into cliché. As Vanity Fair magazine has facetiously asked, 'Is every YouTuber going to make a coming out video eventually?' (Lawson, 2016).

In the late twentieth and early twenty-first centuries, gay and lesbian-identified celebrities have circulated as core textual fabrics upon which non-heterosexual identities have become culturally legible. Richard Dyer (1987) influentially argued that stars and celebrities embody norms of personhood within particular cultural moments, and in a similar way, much queer and poststructuralist theory has sought to elucidate the ways in which categories of sexuality and identity are forged in and through discourse (e.g. Butler, 1990). As an object of analytic scrutiny, the gay or lesbian celebrity can therefore be read through the intersection of these two conceptual frameworks. The star texts of gay celebrities work to produce and delineate highly visible cultural scripts around what it 
means to occupy a gay or lesbian subject position in the contemporary moment. The discursive and semiotic construction of the lesbian/gay celebrities is, in part, the construction of lesbian/gay identity itself within the mainstream cultural imaginary.

Various studies have explored the models of gay identity made visible by particular lesbian or gay celebrities emerging from fields such as music, television and sports, with celebrity coming out narratives featuring particularly prominently within this literature (Dow, 2001; Brady, 2011; Santana, et. Al., 2013; Allen and Mendick, 2014). This collective scholarship shows that to speak of celebrity coming outs en masse would obscure the ways in which different forms of celebrity enable gay/lesbian subjectivities to become legible through these narratives in different, and specific, ways. The scripts of gay life offered by these narratives are inextricably shaped by the discursive conventions of these different typologies of fame, and how these particular modes of celebrity are perceived to speak to cultural notions of, for example, identity, labour and success.

Indeed, different forms of fame each carry their own discursive baggage around the perceived nature, value, meanings and economic rationality of this kind of celebrity. YouTube celebrity is no exception in this regard, and has become culturally construed as a mode of visibility with its own regime of entrepreneurialism, self-branding and the commodification of the 'authentic' self. Moreover, YouTube celebrity has been discussed as speaking in particular to a youth consumer, due to the ages of the celebrities themselves and the modes of address which they employ within their videos (Tolson, 2010; BanetWeiser, 2011; Smith, 2014).

As an emergent typology of celebrity in which lesbian and gay identities have become highly visible, it is therefore important to interrogate and understand how such specificities of YouTube fame have structured the models of gay identity made legible in 
the coming out moments of prominent gay/lesbian vloggers. To do this, in this article, I critically interrogate the mediated coming out narratives of two gay YouTube stars: Ingrid Nilsen and Connor Franta. I explore how Nilsen and Franta's coming outs were structured by the architecture and economy of YouTube celebrity, particularly in relation to the gradual unfolding of vloggers' purportedly 'authentic' selves. In so doing, I argue that, in the circulation of these figures, the specific discourses and conventions of YouTube fame itself work to sculpt and disseminate normative scripts of what it means to be a young gay or lesbian subject in the contemporary, digitised world.

This is an important analytical move. Whilst these texts may seem apolitical in their focus on the personal and emotional contours of the vloggers' lives, they are engaged profoundly in the cultural politics of everyday life. If celebrities circulate as paramount textual frames through which contemporary selfhood is understood (Dyer, 1972), lesbian and gay YouTube stars like Nilsen and Franta can be seen as intervening into both the construction of self-identity for non-heterosexual young people, and contributing to the ways in which gay and lesbian sexualities are made sense of by heteronormative society at large. Moreover, Nilsen and Franta's celebrity texts are important objects of scholarly critique because, in an era of burgeoning visibility and apparent 'acceptance' for sexual minorities across the global West, they emphasise the role of celebrity in demarcating the conditions of this acceptance. I argue that through their construction as celebrities, the ultimate form of 'symbolic validation' in contemporary society (Couldry, 2000), the model of gay youth subjectivity articulated by Nilsen and Franta becomes privileged within the contemporary cultural imaginary as the most 'valid' or 'acceptable' way to inhabit a lesbian or gay subject position. Not coincidentally, this subject position - which I term proto-homonormativity - reinforces rather than challenges the take-for-granted 
normativity of heterosexuality, and seeks to align gay youth identity with the neoliberal rationalities encapsulated within the concept of YouTube celebrity.

\section{$\underline{\text { Case Studies }}$}

With over 9 million collective subscribers, Ingrid Nilsen and Connor Franta are not only some of the most successful gay YouTube stars, but some of the most visible YouTube celebrities in general. Like the majority of prominent gay YouTubers, they have each had highly visible coming out moments: both were presenting as heterosexual when they rose to prominence as vloggers within the YouTube economy, and published videos in which they revealed they were gay and discussed their experiences of coming to terms with their non-normative sexualities. At the time of writing, Franta's video 'Coming Out' (uploaded 8 December 2014) has been watched over 10 million times, while Nilsen's 'Something I Want You To Know (Coming Out)' (9 June 2015) tallies at over 14 million views. Focusing on a female and a male vlogger emphasises how the cultural work of YouTube celebrity coming outs traverses lesbian and gay male identities. I acknowledge, however, that Nilsen and Franta's genders to inflect their celebrity texts in different ways, particularly in terms of Nilsen's self-branding as an expert in fashion and beauty consumption.

It is also important to note that coming out videos have become a prolific subgenre on YouTube (Alexander and Losh, 2010). As such, Nilsen and Franta's coming out vlogs are situated at the more visible end of a continuum of mediated coming outs, densely populated by amateur users of the YouTube site. In order to examine how coming out online functions in the specific context of YouTube celebrities, I therefore approach these videos not as standalone texts, but as interwoven with Nilsen and Franta's broader celebrity personas. These personas are comprised of a matrix of texts, encompassing the 
coming out videos themselves, the vloggers' other video outputs, and interviews with the vloggers in mainstream news media in which their coming out 'journeys' have been discussed. I have also selected these case studies because both Nilsen and Franta have recently diversified into more traditional domains of celebrity culture. Nilsen is a 'Glambassador' for the CoverGirl cosmetics brand, a judge on the reality television show Project Runway: Threads (Lifetime, 2014- ) and has hosted a livestream interview with US president Barack Obama at the White House. At age 23, Franta has published a memoir, A Work in Progress, which reached the New York Times bestseller list, and launched a range of product lines including clothing, coffee and music compilation albums. For these vloggers, the expansion of their celebrity brands, both within YouTube and beyond, is fused with their simultaneous transitions from straight/closeted to openly gay. This discursive entanglement crystallises the subject position which traverses the personas of myriad gay YouTube celebrities, and exemplifies the centrality of discourses of YouTube celebrity itself in producing the modern gay youth subject position which these celebrities make legible.

\section{Defining YouTube Celebrity}

Distinct from celebrities whose fame originated in other areas but who maintain a presence on YouTube, in this article YouTube celebrity denotes an individual whose celebrity stems directly from their activities on the site. The archetypal YouTube celebrity text is the video blog, or 'vlog.' Most conventionally, vlogs involve an individual in a domestic setting, talking in confessional style into a static camera, with seemingly minimal editing. With antecedents in reality TV, webcam culture and other confessional media, the aural content of vlogs generally concern the divulging of personal 'truths' from the vlogger to an imagined audience, who are addressed in the first person in a conversational mode of address (ubiquitously, 'you guys') (Burgess and Green, 2009). 
The topics of revelation within vlogs pertain to a spectrum of emotional registers, ranging from humorous anecdotes from the vloggers' day-to-day lives, to highly personal and emotional revelations, including videos in which vloggers have come out as lesbian or gay. These confessions are situated within an economy of authenticity, where they are shared in exchange for quantifiable signifiers of popularity: video views, subscribers, comments, thumbs up, and shares to other digital platforms, which in turn can be translated into celebrity status and monetary gain (Burgess and Green, 2009). There are, however, many millions of vlogs on YouTube, coming out videos or otherwise, in which users purport to reveal intimate details about their lives and identities. Clearly, not all of the people who feature in and upload these vlogs can be considered YouTube celebrities, at least if the concept of celebrity is to have meaning in relation to YouTube.

A number of crucial factors separate YouTube celebrities such as Nilsen and Franta from the more anonymous majority who consume their images. Foremost is the dialogic asymmetry between the most popular vloggers and their viewers. For YouTube celebrity vlogs such as the coming out videos I address here, while users copiously interact with the video text through commenting, liking, and so on, the density of user interaction means that celebrity vloggers rarely reply to or engage in dialogue with their fans, outside of their address within the videos themselves. This unequal dynamic replicates the dynamics of traditional celebrity consumption (Marwick, 2016),

Further, alongside many other prominent YouTubers, Nilsen and Franta are both YouTube 'partners'. This means that their videos are embedded with various forms of third-party advertising, part of the revenue from which is paid to the partner her/himself. Sarah Banet-Weiser (2012) has discussed the YouTube partner system as enabling selfexpression on the site to be translated into a kind of commercial labour, and in 2015 , 
Nilsen and Franta's net worth, the bulk of which comes from advertising revenue, was estimated at $\$ 300,000$ (USD) for Nilsen ${ }^{\mathrm{i}}$ and $\$ 3$ million (USD) for Franta. ${ }^{\text {ii }}$ Unsurprisingly, both are able to support themselves working full time as vloggers, and both are represented by the talent agency Big Frame, which specialises in 'home-grown' celebrities who have emerged from digital media (Faletta, 2014; Weiss, 2014). For individuals such as these, vlogging is a lucrative form of labour rather than an amateur pursuit. Whilst their vlogs are semiotically constructed as vernacular productions, they in fact circulate as high-value commercial products, embedded within the corporate income streams of YouTube and its parent company Google.

Banet-Weiser $(2011 ; 2012)$ and Daniel Smith (2014) have also discussed the making and uploading onto YouTube of videos featuring oneself as a technique of 'self-branding.' 'Self-branding refers to the ways in which users perform their identities on social media in ways that seek to accrue associations between the individual and particular values and ideals, much like a traditional branded commodity. These self-brands circulate throughout, and sometimes beyond the digital landscape, generating various kinds of symbolic and material capital. Banet-Weiser (2011: 278) describes the self-branded YouTube user as a 'contemporary interactive subject who realises her individual empowerment through and within the flexible, open architecture of online spaces.' This subject position, which is visibly manifest in the figure of the YouTube celebrity, brings together the democratic promise of participatory, digital media with the neoliberal valorisation of entrepreneurialism, self-sufficiency and individual enterprise as the route to capitalistic success (ibid).

The formal content of vlogs - the verbal sharing of the 'authentic' self - may well, however, appear divorced from notions of labour, talent and skill, at least as these 
concepts are traditionally understood. Rather, it is in their likeable, relatable, often slightly comedic personalities, and in their willingness to share personal information, that the commercial appeal of vloggers rests. Yet, rather than simply replicating the 'famous for being famous' model of celebrity discursively associated with reality TV stars, for example, YouTube celebrity is inextricably bound to neoliberal ideals of individualised, entrepreneurial labour, because YouTube celebrities do not initially have access to the celebrity-making resources of mainstream media. For many popular YouTubers, the building of their celebrity personas through this highly individualised regime of authenticity-as-labour has enabled their self-brands to diversify from their foundational careers on YouTube and into more traditional areas of celebrity mediation. Crucially, this is only after they had already attained a status of well-knowingness within YouTube itself, through the production and circulation of self-produced, digital texts. These ventures beyond YouTube work to position vloggers such as Nilsen and Franta within ascendant career narratives in which they have transcended their initial locations as amateur users of the YouTube platform, become integrated within the professional and commercial structures of the site, and now move within the more 'official' domains of commercial celebrity culture. A media/ordinary hierarchy (Couldry, 2000) is thus mapped onto the YouTube economy, where success is defined as the ability to travel beyond YouTube itself through the neoliberal techniques of self-branding and individual enterprise opened up by participatory digital technologies.

\section{Homonormativity and proto-homonormativity}

In their construction as entrepreneurial success stories, who have looked to the self as an economic resource and prospered on the neoliberal market of YouTube fame, Nilsen and Franta embody what scholars have termed a 'homonormative' subject position. Homonormativity refers to the notion that gays and lesbians should mould their lives and 
identities upon existing, heterosexual norms. As an analytical concept, homonormativity is used to critique the ways in which these assimilatory ideals are espoused through various socio-cultural, economic and political processes in which some sexual minority identities have been discursively re-positioned from the abject margins of society to potentially accepted, integrated and productive members of the social body in numerous Western nations. Alongside the assimilation of gays and lesbians within hegemonic ideals of kinship (marriage, monogamy and the nuclear family), consumption (Sender, 2004) and nationhood (Puar, 2007), most significantly for my argument here, homonormativity points towards the imperative for sexual minorities to become exemplary labourers within the neoliberal workforce (Leimbach, 2011).

Lesbian and gay celebrities have been discussed as key bearers of homonormativity within popular culture (Leimbach, 2011). However, the commercialisation of their sexualities notwithstanding, Nilsen and Franta's celebrity texts do not sit entirely comfortably within the logic of homonormativity due to the explicit address to a youth consumer within their coming out vlogs. As Rob Cover (2013: 340) has noted, the subject of homonormativity is inherently an adult, a specificity 'best witnessed in the gradual shift in lobbying toward gay marriage, civil unions, and other rights claims that are based on domestic, coupled partnerships [...] Youth cannot necessarily perform that particular mode of non-heterosexuality.'

As such, whilst Nilsen and Franta embody homonormative identities, their star texts make legible what I am terming a proto-homonormative subject position, which speaks specifically to young gays who fall outside the address of homonormativity proper. As a representational paradigm, proto-homonormativity becomes manifest in the discursive 
'gap' between homonormativity and gay youth, offering young lesbian and gay people an ontological strategy for transitioning into a 'successful' gay adulthood in the future.

In terms of the particular iteration of proto-homonormativity enacted by lesbian/gay YouTube celebrities, a 'successful' or 'ideal' gay adult life is defined through the neoliberal ideals of self-sufficiency, entrepreneurialism and individual enterprise encapsulated in the phenomenon of YouTube celebrity itself. Homonormativity has been discussed as the permeation of neoliberal rationalities into the domain of queer sexualities (Duggan, 2003). The proto-homonormativity of gay YouTube celebrities makes this link between homonormativity and neoliberalism clearer, proffering the ability for these sexual minority subjects to prosper in the neoliberal marketplace of YouTube fame as ratification of the "legitimacy" of the models of gay and lesbian selfhood which they embody and articulate.

If homonormativity denotes a particular relationship between the gay subject and society: allegiant, integrated and productive, proto-homonormativity proposes a particular relationship with the self, characterised by self-acceptance, self-love and pride, which is positioned to enable the homonormative bond between the adult gay subject and the social body in months or years to come. Crucially, in the context of gay YouTube celebrities, the proto-homonormative subject position is inextricably produced through the specific discourses, conventions and economy of YouTube celebrity itself, particularly in relation to the ideals and practises of authenticity, self-branding and selfrevelation.

\section{Coming out in the YouTube celebrity economy.}

YouTube celebrity has become an especially fertile space for the production of gay and lesbian subject positions. This is partly because mediated coming out narratives fit 
squarely within the logic of YouTube fame as an economy of self-branding through revelations of the authentic self. Nilsen and Franta's coming out videos are almost identical in form, narrative and structure. Each sit in front of a static camera, with the mise-en-scène of their domestic apartments visible in the background of the shot. The vloggers begin by straightforwardly asserting that they have something to share with their viewers: they are gay, and then launch into autobiographical monologues, narrating a journey of sexual awakening. A childhood in which they always 'felt different' from other children morphs into teenage years characterised by a dawning awareness of their queer sexualities, which induces no small amount of fear and isolation. They then move on to describing recent processes of leaning to accept and be proud of their authentic gay selves, which has culminated in these mediated coming out moments.

This narration of gay selfhood as an existential journey from shame and secrecy to authenticity and pride is far from unique to YouTube, and marks the migration of a highly recognisable script of gay life into the digital arena. Nilsen and Franta's vlogs replicate almost entirely Ken Plummer's (1995: 84-86) description of the archetypal coming out 'story' of the late twentieth century: 'a complex process of moving from a heterosexual (and confused) identity' to a 'consistent, integrated sense of self' which 'exists not just for oneself alone, but is also at home in the wider world.' In the context of the coming out vlog, however, this narrative of gay life converges with established conceptions of YouTube as a space of authenticity and self-realisation through narration. As Eve Sedgwick (1990) influentially theorised, gay subjectivity is a performative identity which, as it is not written on the body, can only become publicly legible through verbal articulation. Within the popular imaginary, coming out is configured, somewhat paradoxically, as the making tangible through discourse of an ever-present 'truth' of the self. Sedgwick (ibid: 3) described how 'modern Western culture has placed what it calls 
sexuality in a more and more distinctly privileged relation to our most prized constructions of individual identity, truth, and knowledge.' In the context of YouTube, this conception of coming out as the making public of authentic, but previously hidden self, has slotted almost seamlessly within the logic of the vlog as a space for emotional confession and the sharing of personal truths (Alexander and Losh, 2010).

What is unique to the reproduction of this narrative by YouTube celebrities are the location of these celebrities, and the vlogs which they produce, within an economy of authenticity, in which the vlogger has been rewarded with celebrity status, monetary gain and the expansion of their image in the mainstream media through the sharing of 'authentic' details of their private lives. Moreover, the articulation of this coming out paradigm by those who have attained the symbolic validation of celebrity status legitimises this particular script as the expected or normative narrative of contemporary gay subjectivity. The discursive melding of celerity, sexuality and the authentic self, as produced in Nilsen and Franta's coming out vlogs, speaks to a decades long history in which the invitation to uncover celebrities' 'real' selves has been central to the commercial logic of stardom (Dyer, 1986). In the present moment, new media platforms like YouTube are popularly perceived as modes of representation which offer the most unexpurgated access to celebrities' authentic selves. These platforms - seemingly accessed by celebrities themselves on their personal Smartphones or computers - are seen to bypass the intervention of agents, publicists and other professional image-makers (Ellcessor, 2012). Precisely because of this discursive association of new media with authenticity, several 'traditional' celebrities, such as the British Olympic diver Tom Daley, have used YouTube vlogs to publicly come out. 
The coming out vlogs of celebrities like Nilsen and Franta, who have emerged into fame directly from YouTube, therefore circulate at the apex of this discursive process. Andrew Tolson (2010) and Emma Maguire (2015) have noted that YouTube vloggers are often perceived as more authentic than celebrities emerging from traditional media due to the seeming absence of institutional gatekeeping and manipulation in the production and distribution of vlogs. YouTube celebrity coming outs are a two-way productive process: the ideals of authenticity attached to the vlog form work to reproduce the essentialist dialectic of the coming out paradigm, which simultaneously reconfirms and re-solidifies YouTube vlogs as points of access to celebrities' 'real' or 'authentic' selves.

For Nilsen and Franta, their coming out moments were each incorporated into the promise of authenticity upon which their celebrity is made and maintained. Crucially, as noted previously, neither of these vloggers were 'out' as gay when they rose to prominence as YouTube vloggers; they were already celebrities when their coming out videos were published. This enabled their coming outs to operate as commercial resources which functioned to sustain and increase their existing celebrity brands, intensifying the ideals of authenticity and self-revelation already bound to their celebrity personas. For instance, at the end of his coming out video, Franta states:

In true Connor Franta fashion, I'm gonna end my videos like I always do, because this is just another video, it's just another video where you've found out a little more about me. So until next Monday, make sure you give this video a big thumbs up, leave a comment below, check out my other videos, click subscribe. Bye!

These words embed Franta's coming out within a transactional regime where details of his personal life are shared in exchange for quantifiable signifiers of his popularity within the YouTube platform, which can be translated into both monetary gain and the further 
circulation of his celebrity brand. His gay sexuality is slotted into this digital economy as another facet of his authentic self which has been made available for public consumption. To similar effect, addressing her viewers, Nilsen states:

I'm sitting here today because I care about you guys, you've been a part of my life for the past, you know, almost six years, and this [her sexuality] is a really big part of my life. And I want to sit down with you and have this conversation with you just like I've had this conversation with friends and with people who are close to me.

In this statement, Nilsen evokes a network of intimates, encompassing her 'real life' friends and family, and extending para-socially to her viewers, subscribers and fans. Coming out online is construed as the ultimate evidence of Nilsen's closeness, openness and loyalty to those who consume her image, values upon which YouTube celebrity brands are inextricably forged.

It is important to emphasise, however, that YouTube celebrity's regime of authenticity is quite different from that of traditional celebrity-centric media, in a way that has been particularly suited to the reproduction of coming out narratives. In relation to "regular" celebrities, authenticity has been largely conceptualised as an inter-textual struggle, where different texts compete to offer the most "truthful" representation of a star or celebrity (Meyers, 2009). In the context of YouTube celebrity, however, the logic of authentic self-revelation functions within a more symbiotic process, where an authentic persona is gradually built up as the vlogger's video output expands, and more and more personal information is made public. This incompleteness is vital to the function of YouTube celebrity, enabling vloggers' lifespans as celebrities to be extended temporally 
and across texts and platforms, under the aegis of a seemingly ever-increasing intimacy between vlogger and viewer.

For instance, in her coming out vlog, Nilsen explicitly states that there are aspects of her coming out journey that she is choosing not to share in this particular video. Discussing the difficulty of growing up in an environment where 'homosexuality was not widely accepted', she says, 'I'm not going to go into specific details because this is something that is very, very personal, and I want to keep that private.' And later, 'Between my relationships with guys, I have had encounters with women and, again, I'm not going to go into specific details.' Lines such as these evoke an epistemological 'gap' between what Nilsen is making publicly known and what she is withholding. However, as her very identification as a lesbian was, up to this point, something which she had chosen not to share, in this gap between the known/unknown/yet-to-be-known, emerges the possibility that these deferred revelations could become points of access to Nilsen's authentic self in future videos.

Indeed, the notion of coming out as a temporal and existential process of coming to terms with one's authentic self and gradually making this public converges seamlessly with the logic of celebrity vlogging as a gradual sharing of the authentic self over time and across video texts. One does not just come out once; in a culture where bodies are coded as heterosexual by default, coming out is a recurrent and repeated process, addressed to different people at different times, congruent with how comfortable or intimate one feels with these people at these times (Sedgwick, 1990: 68). When Nilsen tells viewers, 'I want to sit down with you and have this conversation with you just like I've had this conversation with friends and with people who are close to me,' she positions her decision 
to finally re-code her identity as lesbian within her public self-representations as a measure of the growth of intimacy between herself and her audience.

Nilsen and Franta's insertion of their coming outs within the promise of eventual, intertextual unfolding of their apparently authentic selves inextricably embeds these revelations within the commercial structures and imperatives of YouTube celebrity, and the specific models of authenticity in which it circulates. Both Nilsen and Franta appear to have actively mobilised their coming outs to augment the para-social intimacy upon which their celebrity is forged, and to extend their celebrity brands. Nilsen's construction of her coming out as a form of self-realisation enabled her to combine her primary vlogging focus on fashion and beauty consumption with output based upon a claimed expertise in accepting and realising one's authentic self. A profile in Women's Health magazine noted that, post-coming out, 'Ingrid is wearing less makeup than ever before and is instead focusing more on inner beauty, personal growth, and relevant social issues' (Abber, 2015); and shortly after coming out Nilsen launched a series of vlogs entitled 'Sense of Self' in which she interviewed other vloggers and minor celebrities from other media about their own journeys to accepting their 'true' selves. Additionally, Franta's coming out was carefully planned (we might speculate) to coincide with the release of his print autobiography, A Work in Progress, where the promise of more revelations about his sexuality functioning to draw consumer to this new venture. In an interview with Huffington Post he was asked, 'being on YouTube, your fans know a fair amount about you. Is there anything you discuss in your book that you haven't gone into in your videos?' to which Franta is quoted to have replied, 'There's a million new things that I talk about [in my memoir] [...] I talk about coming out in more detail and kind of describe the process that I went through with that' (Steyer, 2015). 
Whilst this stretching out of the celebrity brand by gradual revelations of the "authentic" self is common to all YouTube celebrities, the reproduction of the coming out script by gay celebrities situated within this framework discursively sutures the emotional and existential dynamics of the coming out paradigm to the ideals of self-branding, entrepreneurialism and individual enterprise associated with YouTube celebrity. This textual binding of gay identity to the conventions of this particular typology of fame works to produce a subject positions which speaks specifically to young gay and lesbian consumers, mapping out a normative vision of contemporary gay life: protohomonormativity. It is to a detailed analysis of the proto-homonormative subject position, as produced by gay YouTube celebrities, to which I now turn.

\section{$\underline{\text { Proto-homonormativity and coming out as emotional labour }}$}

Within their coming out videos, Nilsen and Franta speak explicitly to a young gay, lesbian or otherwise queer viewer, particularly one who is struggling to come to terms with their sexual orientation. Gay youth consumers are certainly not the limit of these celebrities' fan-bases, but in the context of their coming out moments this is the imagined audience which is evoked both within their vlogs, and in their extra-textual construction as role models for gay youth.

At the close of his coming out vlog, Franta states, 'I'm making this video for anyone who needs it. It's ok. It may not seem like it right now, but you're gonna be fine. I know it's scary, but don't be afraid. You are who you are and you should love that person.' As this quote makes clear, within the vlogs, coming out is represented foremost as an emotional transition, where feelings of fear, shame and isolation are transformed into acceptance and pride in one's non-normative sexuality. Both Nilsen and Franta describe, in highly 
emotive fashion, growing up 'terrified' of being gay, and yearning to 'be normal,' to be 'like everyone else', yet eventually learning to be 'happy' and 'proud' of their sexualities.

This is the crux of the proto-homonormative subject positions which their vlogs and broader celebrity personas make legible: the imperative to transform an anguished and unhappy past, marred by feelings of self-hatred and experiences of homophobia, into a productive and healthy future, through processes emotional work, self-acceptance and self-love. This process of emotional transformation is emblematised in Nilsen and Franta's coming out vlogs. At the same time, both appear to have successfully channelled their emotional and existential transitions into lucrative forms of emotional labour, through the public sharing of their journeys to self-acceptance. Across celebrity culture, the emotional labour of celebrity works to organise the 'affective economy' of public life (Marshall, 1997), offering, through images and discourses of emotion and emotional transformation, discursive tools for the formation of the contemporary self (Redmond, 2016). In channelling emotional expression as a commercial resource in the specific context of coming out, Nilsen and Franta's celebrity texts make legible a series of cultural ideals around the relationship between emotion, sexuality, self and success.

This chain of associations is central to the proto-homonormative subject position which they espouse. Whilst homonormativity refers to the integration of gay subjects within social and political institutions: marriage, the workforce, the nation state (Puar, 2007; Leimnbach, 2011), proto-homonormativity encapsulates the cultural demarcation of a particular kind of selfhood upon which this social integration is positioned as contingent. As articulated in the celebrity texts of Nilsen and Franta, proto-homonormativity discursively draws a connecting line between the gay/lesbian self and the societal integration of sexual minority people. In this framework, a proud and accepting bearing 
upon the self becomes a means of both overcoming socially-produced marginalisation, and of securing one's integration within the normative institutions of labour and polity in the future.

Indeed, the emotionally-felt experiences of marginalisation which Nilsen and Franta discuss within their vlogs stems from the social privileging of heterosexuality as a default norm of personhood and identity. Yet, within their mediations, the route to overcoming this marginalisation is located within highly individualised processes of learning to love and accept this stigmatised identity, thus leaving the source of these feelings unchallenged. This transposition of the social into the personal resonates with a broader twenty-fist century zeitgeist in which cultural texts have repeatedly offered up what Eva Ilouz (2007) has called 'emotional literacy' - the ability to manage, reflect upon and refine the emotional contours of the self - as the route to overcoming all manner socially, politically and systemically ingrained inequalities. Nilsen and Franta's vlogs therefore point to the extent to which proto-homonormativity marks, in some sense, the distillation of this wider culture of emotional literacy into the specific context of lesbian/gay sexualities. As articulated in their coming out narratives, proto-homonormative discourses implicitly reject collective, social or political transformation as the route to attaining more egalitarian sexual paradigms, beyond the logic of heteronormativity. Rather, in proto-homonormative dialectics it is the individual gay or lesbian subject's capacity for self-acceptance and pride in their non-normative sexuality which is positioned as the conduit to individual empowerment, defined as a homonormative future.

Exemplifying this logic almost completely, in his coming out vlog Franta states, '2014 is truly the year that I have accepted who I am, and become happy with that person. So today I want to talk to you guys about that, and be open and honest and tell you that I'm 
gay.' Similarly, Nilsen affirms, 'I want to live my life unapologetically, because I'm proud of who I am, and I'm not going to apologise for who I am anymore.' The politics of heteronormativity thus become diffused into an ethic of self-sufficiency and self-care through the work of emotion. As Franta states:

I kept trying to get myself to look in the mirror and say it [I'm gay]. I couldn't say it, I was not capable of saying it, my mouth couldn’t utter those words. Until one time I did...And I felt...like... a mixture of every emotion possible. I was really relieved that I'd finally said it, and I was also terrified that I'd finally admitted it to myself.

In this passage, the only blockage to self-realisation is himself, coded through a corporeal body which will not let him bring his 'true' sexuality into words. Franta thus positions himself as the agent of his own suffering, locating the capacity of ameliorate this suffering within his own actions and emotions. As Nilsen states at the end of her coming out vlog, 'I'm giving myself my best chance, and so should you.'

In the specific context of gay YouTube celebrities like Nilsen and Franta, the protohomonormative bond between the gay self and the social is also articulated through the suggestion that these young lesbian and gay subjects have drawn upon their emotionally tumultuous experiences of growing up queer, and learning to be proud of their gay sexualities, as core facets of lucrative self-brands which have circulated successfully within the self-revelatory economy of YouTube fame. Nilsen and Franta's incorporations of their affectively-turbulent coming out journeys as means of extending their celebrity brands works to meld a particular vision of neoliberal-capitalist success embodied by the self-branded YouTube star, onto a particular relationship with the gay self. It is in this fusing of gay subjectivity and neoliberal "success" that proto-homonormativity becomes 
manifest. Nilsen and Franta's constructions as exemplary labourers within the neoliberal market of YouTube fame delineates the homonormative rewards which can potentially be reaped from the cultivation of a sense of self in which emotional literacy and selfacceptance, rather than social or political change, are configured as the solution to the psychic costs of heteronormativity.

\section{Role models, aspiration and discipline by example}

In Nilsen and Franta's celebrity texts, outness for gay/lesbian subjects is discursively bound to an accepting, proud and harmonious relationship with one's non-normative sexuality. In turn, this relationship is construed to enable a "successful" gay adulthood, defined through the neoliberal ideals of entrepreneurialism, self-branding, and emotional authenticity emblematised in the figure of the YouTube celebrity vlogger. Nilsen and Franta's coming out trajectories literalise proto-homonormativity's function as a bridge between an affectively-trying queer past and a homonormative future: they discuss not only having learned to love their gay selves, but, in the form of their mediated coming outs, have channelled their non-normative sexualities into commercially lucrative labour within the YouTube celebrity economy.

Within this vision of contemporary gay life, Nilsen and Franta's statuses as celebrities operates centrally as a regime of disciplinarity, implicitly delineating the forms of nonheterosexual identity which are "suitable" for integration within heteronormative society. The ability for some, specific gay and lesbian subjects to attain the symbolic validation of celebrity status sets out the formations of gay identity seemingly required for sexual minorities to prosper in a contemporary, Western social context of apparent equality and acceptance for lesbian and gay subjects. Nilsen and Franta's narratives exemplify how far the proliferation of gay celebrities emerging from YouTube operates as a core facet 
of an emergent, biopolitical incitement to productive engagement in society for sexual minority citizens (Puar, 2007). In this context, the meritocratic architecture YouTube celebrity works to diffuse gay and lesbian people's divergence from the heterosexual norm by reconciling gay and lesbian sexualities with neoliberal-capitalist ideologies of self-sufficiency, entrepreneurialism and individual enterprise, in ways that do not challenge the normativity of heterosexuality or the emotional costs to gay and lesbian life which this entails.

Central to the construction of Nilsen and Franta's interwoven coming out/career trajectories as idealised narratives of contemporary gay life is the 'role model' rhetoric which permeates their celebrity texts. Writing in the context of Dutch-Moroccan ethic minority celebrities, Joke Hermes and Jaap Kooijman (2016: 494) have argued that the discursive construction of role models can function not only as a tool of aspiration, but as 'a form of discipline by example,' in which the role model figure comes to embody the kinds of minority identity deemed 'acceptable' for integration within the status quo.

Exemplifying this logic of aspiration-as-discipline, an interview in Women's Health magazine explicitly positioned Nilsen as a figure of identification, aspiration and emulation for the lesbian and gay youth who consumer her image. It stated:

Of course, Ingrid's coming out video didn't just make her life better; it also impacted her millions of fans. "Just this weekend I had a girl come up to me and say that she felt she had never seen herself reflected in someone who was more of a public figure," says Ingrid (Abber, 2015).

Similarly, in an interview published on the MTV website, Franta is quoted as saying: 
Between my appearance, sexuality, career and beyond, I've struggled greatly in my mere 22 years of existence. I hope my thoughts and advice can help anyone else going through a similar thing and find the confidence they have to persevere (Barker, 2015).

Later in the interview he is asked, 'Your coming out has inspired millions of viewers. Do you have any advice for gay teens who are afraid to come out?' to which Franta is quoted to reply, 'Move at your own pace, don't be afraid - and know that it's going to be okay.' Franta evokes a life trajectory where his own relationship to his sexuality is discursively attached to his career success. His perseverance in the face of adversity, particularly pertaining to his non-normative sexuality, is positioned to have brought both financial remuneration and increased celebrity status, sculpting a model of gay subjectivity which other young gay people are called upon to follow.

As gay celebrity 'role models', Nilsen and Franta are each constructed as individuals who have learned to love and accept their gay selves and, through the democratic promise of digital media, have shaped and channelled this self into lucrative celebrity brands. These brands have successfully ascended to the pinnacle of YouTube fame, and onto the intertextual marketplace of celebrity culture. They thus embody a homonormative subject position as exemplary labourers in the neoliberal marketplaces of YouTube and celebrity culture more broadly. At the same time, their coming out narratives articulate protohomonormative discourses, making legible, without themselves straightforwardly occupying, a proto-homonormative subject position, which is available for identification by the young queer consumers whom their representations address. These celebrities' movements from closeted to out, shame and fear to happiness, pride and self-acceptance are mapped onto their ever-increasing celerity profiles. Prosperity and socio-economic integration for gay and lesbian people in the contemporary era, achieved through the 
neoliberal techniques of self-branding, enterprise and emotional labour, and embodied in the figures of gay YouTube celebrities, is constructed as contingent upon a positive, proud and accepting emotional bearing upon one's marginal identity. This model of subjectivity solidifies the taken-for-granted, socio-cultural dominance of heterosexuality, allotting those outside this sexual norm an apparently productive (defined through neoliberal modes of labour, self-sufficiency and emotional literacy) means of defining themselves in relation to it, in a way that works, ultimately, to reproduce the conditions of their own marginality.

\section{$\underline{\text { Conclusion }}$}

This article has sought to interrogate the prolific entanglements of YouTube celebrity and lesbian and gay identity, through the case studies of Ingrid Nilsen and Connor Franta, focusing in particular on their coming out moments. It is no coincidence that not only are a large number of YouTube celebrities gay and lesbian, but almost all have come out as such after becoming famous, by uploading coming out vlogs. I have argued that normative conceptions of coming out as the eventual realisation and articulation of an authentic truth of the self have converged seamlessly with the specific economy of YouTube celebrity as a gradual, partial and selective sharing of vloggers' purportedly authentic selves over time and across texts. Vloggers such as Nilsen and Franta have mobilised the revelatory rhetoric of the coming out paradigm to expand and develop their existing celebrity brands. The construction and circulation of coming out narratives within and in relation to YouTube celerity has worked to reproduce into the digital age, traditional scripts of coming out as the eventual realisation of an authentic, inner core of the self, as well as position this coming out process as a potential resource which can be productively mobilised as part of a successful self-brand. 
In so doing, YouTube celebrities such as Nilsen and Franta have offered to young gay and lesbian consumers a normative subject position which I have termed protohomonormativity. This is a transitional identity, situated between an affectively turbulent youth and a homonormative adulthood defined in neoliberal terms, as well as a discursive strategy for transforming the former into the latter. Proto-homonormativity, in this context, is produced specifically through the tropes, discourses and economy of YouTube celebrity in various, interconnected ways. These vloggers's apparent mobilisations of their marginal sexualities as forms of emotional labour discursively fuse a particular vision of neoliberal-capitalist success to an emotionally-defined model of 'proud' gay sexuality. This fusing of sexuality and celebrity into a normative gay/lesbian subject position is validated through the valorisation of YouTube celebrities such as Nilsen and Franta as valuable 'role models' for the young gays and lesbians who consume their celebrity texts. In its prolific production of gay-identified stars, YouTube celebrity is inextricably implicated in a contemporary cultural regime in which some sexual minorities have been conferred an unprecedented level of social legitimacy through the compatibility of these identities with the kinds of neoliberal economic rationalities from which the concept of YouTube fame is inseparable, in ways that particularly speaks to gay and lesbian youth. Much like homonormativity (Kennedy, 2014), protohomonormativity evokes a particular raced and classed subject. It addresses white, ablebodied, financially-secure queers, like Nilsen and Franta, whose identities do not intersect with other vectors of oppression, so that their only barrier to self-realisation is constructed as their personal relationships with their sexuality.

Whilst there is much to critique here, it is important to remember that gay YouTube stars such as Nilsen and Franta no doubt do function as valuable figures of identification for many young gay and lesbian people. One only has to read some of the comments beneath 
their coming out videos, where users detail how watching these vlogs has aided them in embracing their marginal sexualities and coming out themselves. Despite profound social, cultural and political shifts in the position of gay subjects within contemporary Western societies, gay people, particularly gay youth, continue to be disproportionately affected by issues such as bullying, mental illness and suicide (Cover, 2013). In this context, the rubric of pride and self-love which these celebrities espouse can be an enabling script, offering a potential lifeline to isolated and marginalised queers who may lack face-to-face communities of non-heterosexual peers.

What is problematic, however, are the ways in which YouTube celebrity's association with enterprising, self-branded models of subjectivity, and the production of gay subjectivities through this lens, works to cement some of the heteronormative ideals which produce the isolation and marginalisation for non-heterosexual people which, contradictorily, these gay 'role models' are positioned to mitigate. Gay and lesbian people, such as Nilsen and Franta, who have prospered on the open market of YouTube fame are represented as those who have learned to simply 'get over' their marginality and 'accept' and embrace their non-normative sexualities through individualised processes of emotional work. This positions various forms of psychic marginalisation as seemingly unavoidable features of modern gay life, simply part-and-parcel of what it means to be a young gay or lesbian person in the contemporary moment.

Moreover, Nilsen and Franta are represented to have translated their processes of overcoming this oppression into lucrative forms of emotional labour, which not only renders unchallenged and unchanged the systemic privileging of heterosexuality within social and cultural life, but paradoxically positions heteronormativity as a potentially enabling force for lesbian and gay youth in the context of neoliberalism. YouTube 
celebrity and gay identity are thus thoroughly enmeshed in a complex and ambivalent ways, whereby particular entanglements of sexuality, celebrity, emotion, authenticity, entrepreneurialism and self-branding become the conceptual matrix through which the contemporary gay or lesbian self is formed.

\section{References}

Abber, C., 2015. How Coming Out Has Given YouTube Star Ingrid Nilsen the Chance to Be Her True Self. Women's Health (19 November). Available from: http://www.womenshealthmag.com/life/ingrid-nilsen-interview

Alexander, L. and Losh, E., 2010. 'A YouTube of One's Own? Coming out as rhetorical action' in C Pullen \& Margaret Cooper (eds), LGBT Identity and Online New Media. Abingdon: Routledge.

Allen, K., Harvey, L. and Mendick, H. 2014. 'Tom Daley's Something I want to say...: examining contemporary celebrity, identity and sexuality. MEJ: Media Education Journal. 55 19-23.

Banet-Weiser, S., 2012. Authentic: The Politics of Ambivalence in Brand Culture. London: New York University Press.

Banet-Weiser, S., 2011. Branding the Post-Feminist Self: Girls' Video Production and YouTube. In Mediated Girlhoods: new explorations in girls' media culture. New York: Peter Lang. 
Barker, T., 2015. 'The thing about the Internet is we take everything too far': YouTube star Connor Franta Opens Up. MTV news (5 May). Available at: http://www.mtv.com/news/2146686/connor-franta-interview/

Bennett, J., 2011. Television Personalities: Stardom and the Small Screen. Abingdon: Routledge.

Brady, A., 2011. 'This is why mainstream American votes against gays, Adam Lambert': Contemporary outness and gay celebrity. Celebrity Studies. 2(3) 292-304.

Burgess J. and Green J., 2009. 'The Entrepreneurial Vlogger: Participatory culture beyond the Professional-Amateur divide,' in The YouTube Reader. P Snickars \& P Vunderau (eds) Stockholm: Mediehistoriskt.

Butler, J., 1990. Gender Trouble. London: Routledge.

Couldry, N., 2000. The Place of Media Power. London: Routledge.

Cover, R., 2013. Conditions of living: Queer youth suicide, homonormative tolerance, and relative misery. Journal of LGBT Youth. 10(4) 328-350.

Dillon, C., 2015. Where are all the successful gay British YouTubers? GT (14 September) [https://www.gaytimes.co.uk/life/7318/craig-dillon-asks-where-are-the-successful-gaybritish-youtubers/]

Dow, B., 2001. Ellen, Television, and the Politics of Gay and Lesbian Visibility. Critical Studies in Media Communication. 18(2) 123-140.

Duggan, L, 2003. The Twilight of Equality?: Neoliberalism, Cultural Politics and the Attack on Democracy. Boston: Beacon Press. 
Dyer, R., 1986. Heavenly Bodies: Film Stars and Society. Basingstoke: Macmillan.

Ellcessor, E., 2012. Tweeting @feliciaday: online social media, convergence, and subcultural stardom. Cinema Journal. 51(2) 46-66.

Faletta, A., 2014. How Vlogger MissGlamorazzi Went From Being Afraid of YouTube to a CoverGirl. Style Caster. Avilable from: http://stylecaster.com/beauty/missglamorazzi-youtube/

Franta, C., 2014. Coming Out [online]. Available from:

https://www.youtube.com/watch?v=WYodBfRxKWI

Hermes, J. and Kooijman, J., 2016. The Everyday Uses of Celebrity. In Companion to Celebrity Marshall and Redmond (eds.) Oxford: Wiley.

Illouz, E., 2007. Cold Intimacy: The Making of Emotional Capitalism. Cambridge: Polity.

Kennedy, T. 2014. Sustaining white heteronormativity: The Kids Are Alright as public pedagogy. Journal of Lesbian Studies. 18

Lawson, R., 2015. Everyone Will Come Out on YouTube Eventually. Vanity Fair (12 June). Available from: http://www.vanityfair.com/culture/2015/06/youtube-digest-june12

Leimbach, J., 2011. Strengthening as they undermine: Rachel Maddow and Suzie Orman's Homonormative Lesbian Identities. In In the Limelight and Under the Microscope: Forms and Functions of Female Celebrity, S Holmes and D Negra (eds.) London: Bloomsbury. 
Maguire., 2015. Self-branding, hotness and girlhood in the video blogs of Jenna Marbles. Biography 38(1) 72-86.

Marshall, P., 1997. Celebrity and Power: Fame in Contemporary America. London: University of Minnesota Press.

Marwick, A., 2016. You May Know Me from YouTube: (Micro-) Celebrity in Social Media. In Companion to Celebrity, P Marshall and S Redmond (eds.) Oxford: Wiley.

Meyers, E. 2009., “Can You handle My Truth?”: Authenticity and the Celebrity Star Image. Journal of Popular Culture 42(5).

Nilsen, I. 2015., Something I Want You To Know (Coming Out) [online]. Available from: https://www.youtube.com/watch?v=Eh7WRYXVh9M

Plummer, K., 1995. Telling Sexual Stories: Power, Change and Social Worlds. London: Routledge.

Puar, J., 2007. Terrorist Assemblages: Homonationalism in Queer Times. Duke University Press.

Redmond, S., 2016. Emotional Celebrity: Introduction. In Companion to Celebrity, P Marshall and S Redmond (eds.) Oxford: Wiley.

Santana, C. et. Al., 2014. Creative (critical) discourse analysis of Tiziano Ferro and Ricky Martin “coming out". Qualitative Inquiry. 20(2) 183-192.

Sender, K., 2004. Business Not Pleasure: The Making of the Gay Market. New York: Columbia University Press. 
Smith, D., 2014. 'Charlie is so 'English'-like: nationality and the branded celebrity person in the age of YouTube. Celebrity Studies 5(3) 256-274.

Steyer, C., 2015. YouTube Star Connor Franta Talks New Memoir, Dealing with Haters And His Dream Vlog Collaboration. Huffpost Teen (21 April). Available from: http://www.huffingtonpost.com/2015/04/21/connor-franta-new-bookyoutube_n_7109560.html

Tolson, A., 2010. A new authenticity? Communicative practices on YouTube. Critical Discourse Studies 7 (4) 277-289

Weiss, G., 2014. How YouTube Megastar Connor Franta Is Channeling His Eclectic Passions Into Entrepreneurial Gold. Entrepreneur (18 December). Available form: http://www.entrepreneur.com/article/241009

\footnotetext{
${ }^{i}$ http://www.the-net-worth.com/2015/06/ingrid-nilsen/ ii http://www.the-net-worth.com/2015/11/connor-franta/
} 